\title{
Assessment of Soil Chemical Properties and Fertility in Some Traditional Irrigation Schemes of the Babati District, Manyara Region, Tanzania
}

\author{
Joachim HJR Makoi \\ National Irrigation Commission (NIRC), Dar es Salaam, Tanzania \\ Email address: \\ joachimmakoi@yahoo.com \\ To cite this article: \\ Joachim HJR Makoi. Assessment of Soil Chemical Properties and Fertility in Some Traditional Irrigation Schemes of the Babati District, \\ Manyara Region, Tanzania. Agriculture, Forestry and Fisheries. Vol. 5, No. 6, 2016, pp. 249-260. doi: 10.11648/j.aff.20160506.16
}

Received: October 18, 2016; Accepted: November 3, 2016; Published: December 21, 2016

\begin{abstract}
Aim: To assess the soil chemical properties and fertility status in selected traditional irrigation schemes in Babati District Council in Manyara Region, Tanzania. Place and Duration of Study: The survey was conducted in Mkombozi, Muungano and Endamajek proposed irrigation schemes, Babati District, in Tanzania during the dry season of 2002. Methodology: Soil sampling was done after the soils were grouped into similar soil types following pedogeomorphic approach whereby eleven (11) mapping units were delineated but only ten (10) mapping units were sampled. Using zigzag sampling techniques, thirty (30) disturbed soil samples were collected at depth $0-30 \mathrm{~cm}$ from the delineated pedogeomorphic units. The soil samples were bulked thoroughly mixed and sub sampled to obtain a representative composite sample and sent for laboratory analysis at the Selian Agricultural Research Institute (SARI), Arusha, Tanzania. Results: The results showed significant difference in the fertility status in the selected sites of each scheme. Based on guidelines of soil nutrient contents established elsewhere, $\mathrm{pH}$ of the soils in the study areas were rated as mildly alkaline in $2 \%$ in Endamajek and moderately alkaline in $80 \%$ in Muungano, $29 \%$ in Mkombozi and $73 \%$ in Endamajek. The soils were also rated as strongly alkaline in $66 \%$ of the area in Mkombozi. Crop production was moderately constrained by sodicity and strongly sodic in $26.6 \%$ of the total surveyed area in Endamajek. TN and OM were low, in Muungano; very low or low to medium,; in Mkombozi and low to medium, in Endamajek respectively. Available $\mathrm{P}$ was rated as low in $74 \%$ and high in $26 \%$ of the area in Muungano; high in Mkombozi as well as medium in Endamajek. Of the total surveyed area, $66 \%$ in Mkombozi and $26.6 \%$ in Endamajek have low CEC. C/N ratio in $46 \%$ of the total area surveyed in Muungano was of good quality suggesting ideal conditions for plant growth as compared with Mkombozi and Endamajek. Results also indicated that $\mathrm{Ca}: \mathrm{Mg}$ ratios to be less than suggested guidelines in $35 \%$ of the surveyed areas in Muungano and all the surveyed areas in Endamajek suggesting that plants would probably respond to the addition of $\mathrm{Ca}$ or $\mathrm{Mg}$ in such areas. Conclusion: The soil fertility status and overall information from this study could be used in fertilizer and sodicity and/or salinity management studies to establish nutrient and drainage requirements for different crops which are grown in these areas.
\end{abstract}

Keywords: Calcium, Cation Exchange Capacity, Crop Production, Sodicity, Fertility Constraints, Management Practices, Soil Organic Matter, Survey

\section{Introduction}

About $90 \%$ of the population in Babati District Council (BDC), Manyara Region, who lives in the rural areas and practise agro-pastoralism for their livelihood have realized that sound profit margins can also be achieved through crop diversification including rice (Oryza sativa L.), maize (Zea mays L) and oil seed crops cultivation. However, cultivation of most of these crops is rainfed and takes place during the long rainy season (Masika). For example in 2012, it was reported that in Manyara Region, about 518,897 ha was put under cultivation during wet season (Masika) as opposed to 11,175 ha $(2.2 \%)$ during the short rains (Vuli). Babati District Council (BDC) has an irrigation potential of 15,988 ha out of which $37 \%$ is under irrigation through different water sources. It is believed that with irrigation improvement and 
development, more area will be put under cultivation particularly during the dry season and reach the full irrigation potential of the District Council. Assured availability of water for irrigation during growth of various crops including paddy will contribute significantly to the economic growth, not only for the people of BDC and Manyara Region, but also will contribute to the overall National Economic Growth. The most commonly grown crops in the District are: maize (Zea mays L.), sorghum (Sorghum bicolor L), pearl millet (Pennisetum glaucum), rice (Oryza sativa L.), beans (Phaseolus vulgaris L), cowpea (Vigna unguiculata L.), groundnuts (Arachis hypogea L.), sunflowers (Helianthus annuus), sweet potatoes (Ipomoea batatas), cassava (Manihot esculenta), and onions (Allium cepa L.). However, farmers in the area have shown interest in paddy cultivation if water availability for irrigation is ensured with a view to address food security within and outside the region as well as economic challenges. Since irrigation development is an expensive undertaking, detailed evaluation particularly on the fertility status of the areas to be developed was necessary. This is because nutrients and nutrients balance is of great challenge in most areas of the district just as in similar environments in the tropics $[1,2]$. Common soil fertility challenges in most areas in the tropics include excessive leaching, chemical degradation, nutrient mining and salinity, decline in soil organic matter and high prices of fertilisers [1, $3,4]$.

Due to these challenges and other complex soil, crop management, farming systems and soil fertility [5] the average yield of paddy in the study area is $1.6 \mathrm{tha}^{-1}$ which is very low compared with a potential of $8 \mathrm{t} \mathrm{ha}^{-1}[1,6,16]$. Although no studies have been conducted on the assessment of soil chemical properties and fertility in Endamajek, Muungano and Mkombozi proposed schemes for irrigation development, experience from studies of similar environments elsewhere in Africa have shown soil fertility decline $[4,7,8,9]$ often leading to low crop production and productivity $[10,11,12,13]$ as may be the case with soils in Babati District Council. Therefore, assessment of soil chemical properties and fertility status in the study areas was necessary and was assessed based on standard key indicators as reported in $[14,15]$ as are realistic in predicting plant growth and development. Assessment and understanding of the soil fertility status based on the attributes described in $[14,15]$ will not only enhance strategies for soil fertility management and land development, but also will provide input into the design and planning of crop nutrition packages in the study areas. To date, studies on soil fertility status in Tanzania are very scarce $[2,9,18]$. The objective of this study was therefore to assess the soil chemical properties and fertility status in the selected irrigation schemes of Babati District, Manyara Region, Tanzania.

\section{Material and Methods}

\subsection{Description of Study Area}

The irrigation schemes of Mkombozi, Muungano and Endamajek each with 250 ha are located in Babati District, Manyara Region, Tanzania. Mkombozi irrigation scheme is located at $4^{\circ} 01^{\prime} 60^{\prime \prime} \mathrm{S}$ and $35^{\circ} 45^{\prime} 57^{\prime \prime} \mathrm{E}$, about $36 \mathrm{~km} \mathrm{NW}$ of Babati town at about $1,341 \mathrm{~m}$ above mean sea level. Muungano irrigation scheme is between Mawemairo and Matufa villages about $21 \mathrm{~km} \mathrm{NE}$ of Babati town dissected by the main road from Arusha to Babati. The Endamajek irrigation scheme is located at $4^{\circ} 18^{\prime} 00^{\prime \prime} \mathrm{S}$ and $35^{\circ} 52^{\prime} 00^{\prime \prime} \mathrm{E}, 25$ $\mathrm{km}$ East of Babati town at an altitude of 1,524 $\mathrm{m}$ a.m.s.1.

These irrigation schemes are generally found on a plain landscape. The climate of the three irrigation schemes is characterised as semi-arid [19]. Rainfall distribution in Mkombozi and Muungano irrigation schemes is fairly bimodal with most of the rains (42.8\%) falling in March through April (24.2\% in April alone) and about $24.4 \%$ in November through December (Table 1, Fig 1). According to these data, about $761.1 \mathrm{~mm}$ of rainfall annually is possible at an altitude of $1,341 \mathrm{~m}$ above mean sea level. Mean annual temperature for Mkombozi and Muungano irrigation schemes is $23.8^{\circ} \mathrm{C}$. June and July are the coldest months, while the warmest months are October up until January. The annual evapotranspiration is about $2,610 \mathrm{~mm}$. Moisture surplus exists between March and April. Humidity Index (HI) shows that April, May and November are humid months $(\mathrm{HI}>1.00)$ (Fig 2). Table (1) shows the summary of the climatic variables as depicted from Magugu TPRI meteorological station. For Endamajek (Qash) irrigation scheme, climate variables from Gallapo mission rainfall data with Lat. $4^{\circ} 18$ "00S; Long. 3552"00E Alt. 1,524 m m.a.s.1 was used. Rainfall distribution in Qash scheme is fairly bimodal with most of the rains (62\%) falling in January through April (18.9\% in April alone) and about $28.3 \%$ if present in November through December (Table 1). According to these data, about $845 \mathrm{~mm}$ of rainfall annually is possible at an altitude of 1,524 $\mathrm{m}$ above mean sea level.

Table 1. Climatic data representative for Mkombozi, Mawemairo/Matufa and Endamajek irrigation schemes.

\begin{tabular}{|c|c|c|c|c|c|c|c|c|c|c|c|c|}
\hline & $\mathbf{J}$ & $\mathbf{F}$ & $\mathbf{M}$ & $\mathbf{A}$ & $\mathbf{M}$ & $\mathbf{J}$ & $\mathbf{J}$ & $\mathbf{A}$ & $\mathbf{S}$ & $\mathbf{O}$ & $\mathbf{N}$ & D \\
\hline $\operatorname{Tmax}\left({ }^{\circ} \mathrm{C}\right)$ & 31.1 & 24.9 & 30.7 & 28.5 & 26.9 & 27 & 26.9 & 28.4 & 29.9 & 31.8 & 31.5 & 31.5 \\
\hline $\operatorname{Tmin}\left({ }^{\circ} \mathrm{C}\right)$ & 18.6 & 19.2 & 20 & 19.5 & 18.7 & 16.4 & 16.2 & 17 & 18.1 & 19.3 & 19.9 & 19.5 \\
\hline Tmean $\left({ }^{\circ} \mathrm{C}\right)$ & 24.8 & 22 & 25.3 & 24 & 22.8 & 21.7 & 21.5 & 22.7 & 24 & 25.5 & 25.7 & 25.5 \\
\hline RH (\%) & 74.6 & 74 & 76.3 & 77.6 & 77.2 & 72.9 & 71.7 & 67.8 & 67.1 & 65.3 & 68.4 & 71.8 \\
\hline ETo $(\mathrm{mm} / \mathrm{d})$ & 8.9 & 7.9 & 7.5 & 7.1 & 6.3 & 6.5 & 5.3 & 6.8 & 6.9 & 8.1 & 7.7 & 7.9 \\
\hline ETo $(\mathrm{mm} / \mathrm{m})$ & 268 & 236 & 226 & 212 & 190 & 196 & 159 & 204 & 208 & 242 & 232 & 237 \\
\hline $0.5 \mathrm{ETo}(\mathrm{mm} / \mathrm{m})$ & 134 & 118 & 113 & 106 & 95 & 98 & 79.5 & 102 & 104 & 121 & 116 & 118.5 \\
\hline E-Pan A (mm/d) & 11.2 & 6.7 & 6.4 & 7 & 5.5 & 5.7 & 7.7 & 10 & 11.7 & 8 & 9.7 & 8.6 \\
\hline E-Pan A (mm/m) & 337 & 200 & 192.3 & 209.3 & 166 & 171 & 229.6 & 299.4 & 350.4 & 240 & 292 & 257 \\
\hline
\end{tabular}




\begin{tabular}{|c|c|c|c|c|c|c|c|c|c|c|c|c|}
\hline & $\mathbf{J}$ & $\mathbf{F}$ & $\mathbf{M}$ & A & $\mathbf{M}$ & $\mathbf{J}$ & $\mathbf{J}$ & A & $\mathbf{S}$ & $\bar{O}$ & $\mathbf{N}$ & $\bar{D}$ \\
\hline Wind (mil/d) & 83.4 & 80.4 & 90.8 & 87.1 & 85.2 & 74.8 & 86.6 & 78.7 & 88.4 & 96 & 91.1 & 100.1 \\
\hline $\mathrm{R}(\mathrm{mm})$ (Gallapo mission) & 110 & 111 & 143 & 160 & 63 & 7 & 1 & 0 & 2 & 9 & 84 & 155 \\
\hline $\mathrm{R}(\mathrm{mm})$ (TPRI Magugu) & 97.8 & 85 & 141.3 & 184.3 & 45.9 & 4.5 & 0.2 & 1 & 3.3 & 12.3 & 73.1 & 112.5 \\
\hline
\end{tabular}

Source: Magugu and Gallapo Station, ETo = Potential evapotranspiration, $\mathrm{RH}=$ Relative humidity, $\mathrm{SSR}=$ Solar Radiation, $\mathrm{SH}=\mathrm{Sunshine}$ hours

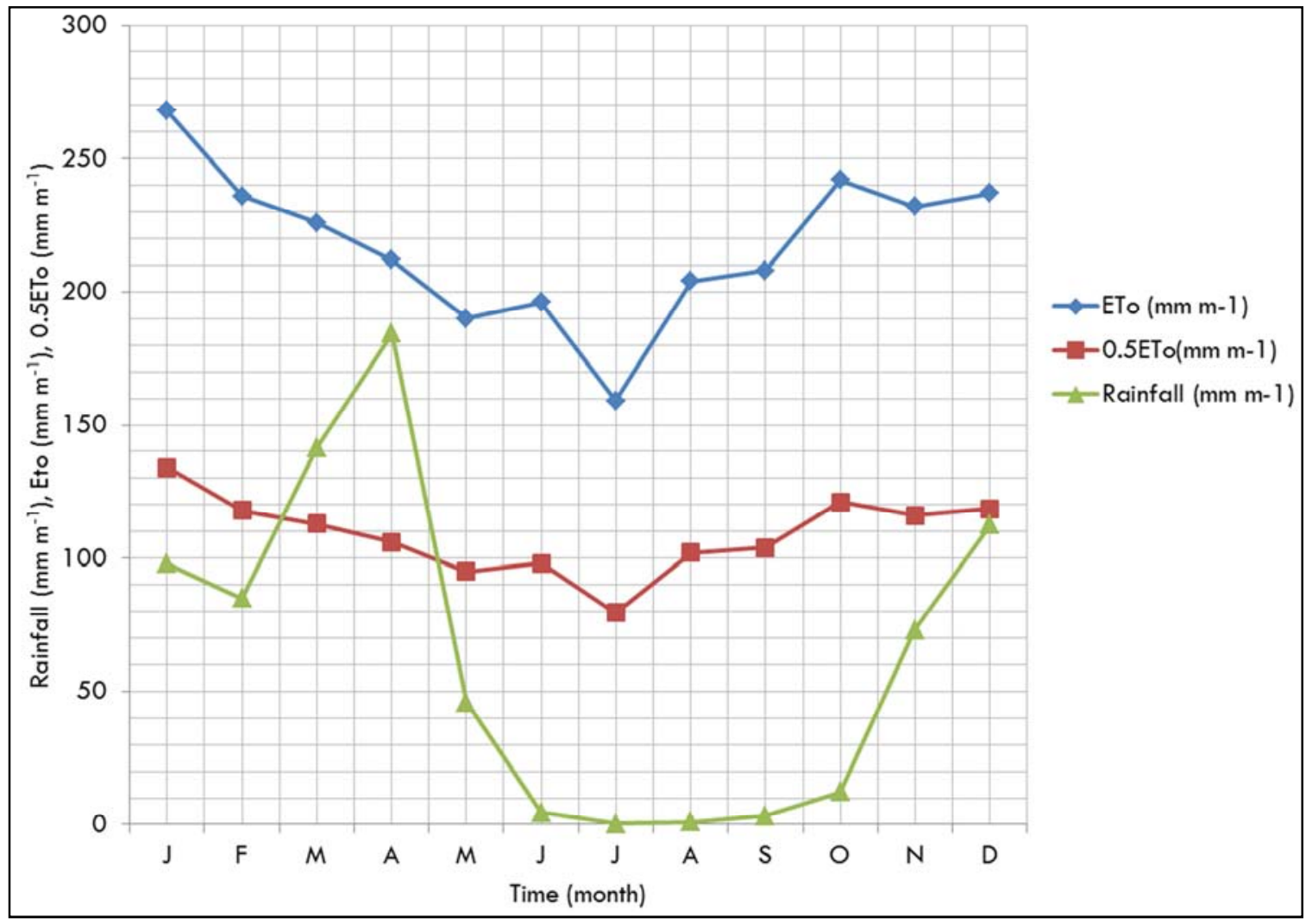

Figure 1. Water balance and the determination of the growing period for the selected schemes.

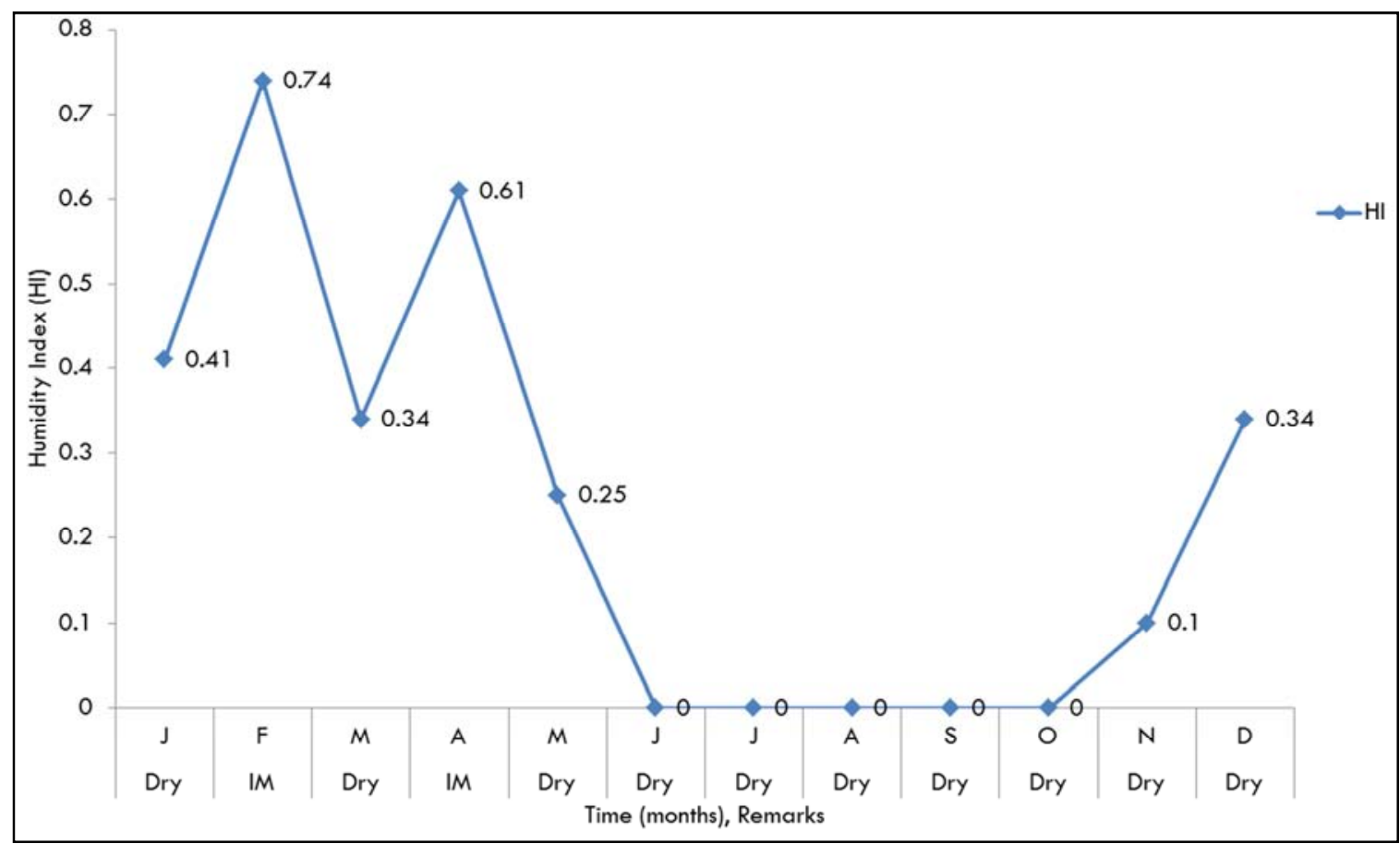

Figure 2. Humidity index (HI) for the selected sites of Babati District, Manyara Region, Tanzania. 


\subsection{Soil Sampling}

Soil sampling in the Muungano, Endamajek and Mkombozi target areas was done after the soils were grouped into similar soil types or pedons following pedogeomorphic approach [20] whereby eleven (11) mapping units were delineated but only 10 mapping units were sampled. Of the eleven (11) mapping units, eight (8) were from Muungano and Endamajek (Qash) irrigation schemes i.e. four (4) mapping units each, and three (3) from Mkombozi (Gichameda) irrigation scheme. Using zigzag sampling techniques, thirty (30) disturbed soil samples were then collected at depth $0-30 \mathrm{~cm}$ from the delineated pedogeomorphic units. Soil samples from each soil type were bulked, thoroughly mixed and sub sampled to obtain a representative composite sample. After the soil samples were filled in plastic bags and labelled, they were sent for laboratory analysis at the Selian Agricultural Research Institute (SARI), Arusha, Tanzania. In the laboratory, the samples were air dried and then ground to pass through a 2$\mathrm{mm}$ sieve for determination of physical chemical fertility indicators. These disturbed samples were divided into four (4) sub-samples to obtain four (4) replicates after which they were analysed separately.

\subsection{Soil Physicochemical Indicators}

Particle size analysis was determined by Bouyoucos hydrometer method after dispersion with $5 \%$ sodium hexametaphosphate [21] and textural classes were determined using the USDA textural class triangle [17]. Organic carbon was determined by the Walkley and Black wet oxidation method [22] and OC was converted to organic matter (OM) by multiplying by a factor of 1.724 [23]. Soil reaction was measured potentiometrically in water and $1 \mathrm{~N}$ $\mathrm{KCl}$ at a ratio of 1: 2.5 soils: water and $\mathrm{KCl}$ [24]. Total nitrogen was determined using micro-Kjeldahl digestiondistillation method [25].

Determination of $\mathrm{Ca}, \mathrm{Mg}, \mathrm{K}, \mathrm{Na}$ referred to as exchangeable bases and CEC referred to as cation exchange capacity depended on soil reaction. In soils with $\mathrm{pH}<7.5$, were extracted by saturating soils with $1 \mathrm{M}$ ammonium acetate $\left(\mathrm{NH}_{4} \mathrm{OAc}\right)$ at $\mathrm{pH} 7$, ethanol and acidified $1 \mathrm{MKCl}$ in the first percolate [26]. The absorbed $\mathrm{NH}_{4}{ }^{+}$displaced by $\mathrm{K}^{+}$ using $1 \mathrm{M} \mathrm{KCl}$ was then determined by Kjeldahl distillation method for the estimation of CEC of the soil. For soils with $\mathrm{pH}>7.5$ and high carbonates contents, the method recommended by [27] was followed. Determination of K and $\mathrm{Na}$ was done with flame photometer, $\mathrm{Ca}$ and $\mathrm{Mg}$ by Inductively Coupled Plasma Atomic Absorption Emission Spectrophotometer [28]. Cation exchange capacity (CEC) was done following the method by [28]. Potentiometric method was used to determine electrical conductivity (EC) of soil samples following the procedure described by [29]. The total exchangeable bases (TEB) were calculated arithmetically as a sum of the four exchangeable bases $\left(\mathrm{Ca}^{2+}\right.$, $\mathrm{Mg}^{2+}, \mathrm{Na}^{+}$and $\mathrm{K}^{+}$) for a given soil sample. Available $\mathrm{P}$ was extracted spectrophotometrically [30] by reacting with ammonium molybdate using ascorbic acid as a reductant in the presence of antimony, as in [31]. The total exchangeable bases (TEB) were obtained as the sum of exchangeable $\mathrm{Ca}$, $\mathrm{Mg}, \mathrm{K}$ and Na. Per cent base saturation (\% BS) was obtained by dividing TEB by CEC and then multiplied by 100 [32]. Exchangeable sodium percentage (ESP) was obtained by dividing total exchangeable sodium by $\mathrm{CEC}$, and then multiplied by 100 . The K: TEB was obtained by dividing $\mathrm{K}$ by TEB.

Statistical analysis: One-way ANOVA was used to compare soil mineral elements from the different pedogeomorphic units. The analysis was performed using the STATISTICA software of 2016 version (StatSoft Inc., Tulsa, OK, USA). The mean values were compared at $5 \%$ level of significance using least significant differences (L. S. D) test.

\section{Results and Discussion}

\subsection{Soil Reaction}

Results of Table (2) which represent Muungano irrigation scheme, showed that $\mathrm{pH}$ of the top soils ranged from 7.1 to 7.8. These were rated as neutral to mildly alkaline. In Mkombozi scheme, soil $\mathrm{pH}$ of the top soils ranged from 8.4 to 8.8 in the top soil that rated as moderately alkaline to strongly alkaline. Regarding Endamajek (Qash) irrigation scheme, $\mathrm{pH}$ ranged from 7.5 to 8.0 in the top soils that rated as mildly alkaline to moderately alkaline. Soil $\mathrm{pH}$ is an important indicator in assessing soil fertility and its environment. For example, the normal $\mathrm{pH}$ range for optimal mineral elements availability for most crops is 6.0 to 7.5 [34; 35]. However, the soil in the studied areas (Mkombozi and Endamajek) were rated as moderately to strongly alkaline (Table 2,3) [33] suggesting that mineral elements deficiency such as $\mathrm{P}, \mathrm{Ca}, \mathrm{Fe}, \mathrm{Cu}, \mathrm{Zn}, \mathrm{Mn}$ and Mo are likely to occur [36; 37; 38]. Furthermore, unfavourable plant growth conditions such as severe root damage, shallow rooting, poor root development, susceptibility to drought and poor use of subsoil mineral elements have been reported in such $\mathrm{pH}$ range $[39,40]$. Collectively, the constraints associated with alkaline conditions may threaten the yield potential particularly in all the study areas. In order to reverse this trend, soil $\mathrm{pH}$ has to be reduced to the acceptable range by acidification using different options. For example, adding elemental $\mathrm{S}$ to the soil will undergo chemical reaction with $\mathrm{H}_{2} \mathrm{O}$ and $\mathrm{O}_{2}$ to form sulfuric acid $\left(\mathrm{H}_{2} \mathrm{SO}_{4}\right)$ in the presence of sulfur-oxidizing bacteria which eventually plays the role of reducing the soil $\mathrm{pH}$. Likewise, addition of $\mathrm{Fe}$ and $\mathrm{Al}$ compounds in the soil reacts with $\mathrm{H}_{2} \mathrm{O}$ to release $\mathrm{H}^{+}$ion which lowers $\mathrm{pH}$. When soil microbes decompose plant materials or when humus is decomposed, carbonic acid $\left(\mathrm{H}_{2} \mathrm{CO}_{3}\right)$ and organic acids are released which lowers the soil $\mathrm{pH}$. Soil $\mathrm{pH}$ is similarly lowered after $\left(\mathrm{NH}_{4}\right)_{2} \mathrm{SO}_{4}$ is nitrified into $\mathrm{NO}_{3}{ }^{-}$and $\mathrm{H}^{+}$ions by soil bacteria. 
Table 2. Soil fertility data for the selected sites of Babati (topsoil samples 0-30 cm depth).

\begin{tabular}{|c|c|c|c|c|c|c|c|}
\hline \multirow{2}{*}{ Sample No. } & \multirow{2}{*}{ Texture } & pH & EC & OC & TN & \multirow{2}{*}{$\mathbf{C} / \mathbf{N}$} & \multirow{2}{*}{$\frac{\text { Avail. P }}{\left(\mathrm{mg} . \mathrm{kg}^{-1}\right)}$} \\
\hline & & $\left(\mathrm{H}_{2} \mathrm{O}\right)$ & $\left(\mathrm{dS} . \mathrm{m}^{-1}\right)$ & $(\%)$ & & & \\
\hline \multicolumn{8}{|c|}{ MUUNGANO (MAWEMAIRO/MATUFA) } \\
\hline Mu-P1 & $\mathrm{CL}$ & $7.10 \mathrm{~b}$ & $0.05 \mathrm{~d}$ & $1.08 \mathrm{c}$ & $0.10 \mathrm{a}$ & $11 \mathrm{c}$ & $3.03 \mathrm{~b}$ \\
\hline $\mathrm{Mu}-\mathrm{P} 2$ & SCL & $7.80 \mathrm{a}$ & $0.14 \mathrm{c}$ & $0.85 \mathrm{~d}$ & $0.05 \mathrm{~b}$ & $17 \mathrm{a}$ & $1.47 \mathrm{c}$ \\
\hline Mu-P3 & SCL & 7.60ab & $0.17 \mathrm{~b}$ & $1.18 \mathrm{~b}$ & $0.10 \mathrm{a}$ & $12 \mathrm{bc}$ & $23.72 \mathrm{a}$ \\
\hline Mu-P4 & $\mathrm{C}$ & 7.40ab & $0.23 \mathrm{a}$ & $1.25 \mathrm{a}$ & $0.10 \mathrm{a}$ & $13 b$ & $1.70 \mathrm{c}$ \\
\hline \multicolumn{8}{|c|}{ One Way ANOVA (F-Statistics) } \\
\hline F-Value & F-Value & $2.6^{*}$ & $332.2 * * *$ & $48.9 * * *$ & $4.9^{*}$ & $53.5^{* * *}$ & $5465.7 * * *$ \\
\hline CV (\%) & & 4.3 & 4.8 & 4.0 & 22.5 & 4.7 & 3.4 \\
\hline \multicolumn{8}{|c|}{ MKOMBOZI } \\
\hline M-P1 & SL & $8.8 \mathrm{a}$ & $0.08 \mathrm{~b}$ & $0.4 \mathrm{~b}$ & $0.03 \mathrm{~b}$ & $13 \mathrm{a}$ & $22.38 b$ \\
\hline M-P2 & SL-SCL & $8.4 \mathrm{a}$ & $0.47 \mathrm{a}$ & $1.91 \mathrm{a}$ & $0.14 \mathrm{a}$ & $14 \mathrm{a}$ & $33.34 \mathrm{a}$ \\
\hline \multicolumn{8}{|c|}{ One Way ANOVA (F-Statistics) } \\
\hline F-Value & & $2.607 \mathrm{~ns}$ & $211.0^{* * *}$ & $290.8 * * *$ & $739.5^{* * *}$ & $5.9 \mathrm{~ns}$ & $127.4^{* * *}$ \\
\hline CV (\%) & & 10.3 & 5.8 & 10.1 & 1.7 & 13.7 & 22.5 \\
\hline \multicolumn{8}{|c|}{ ENDAMAJEK (QASH) } \\
\hline E-P1 & $\mathrm{C}$ & $7.9 \mathrm{a}$ & $0.41 \mathrm{~b}$ & $1.52 \mathrm{a}$ & $0.11 \mathrm{a}$ & $13 a$ & $5.09 \mathrm{c}$ \\
\hline E-P2 & $\mathrm{C}$ & $7.7 \mathrm{a}$ & $0.05 \mathrm{c}$ & $1.33 \mathrm{~b}$ & $0.10 \mathrm{a}$ & $13 a$ & $7.35 \mathrm{~b}$ \\
\hline E-P3 & $\mathrm{C}$ & $8.0 \mathrm{a}$ & $1.36 \mathrm{a}$ & $1.44 \mathrm{ab}$ & $0.10 \mathrm{a}$ & $14 \mathrm{a}$ & $7.19 \mathrm{~b}$ \\
\hline E-Hi2 & SL- SCL & $7.5 \mathrm{a}$ & $0.08 \mathrm{c}$ & $1.34 \mathrm{~b}$ & $0.10 \mathrm{a}$ & $13 a$ & $9.86 \mathrm{a}$ \\
\hline \multicolumn{8}{|c|}{ One Way ANOVA (F-Statistics) } \\
\hline F-Value & & $1.0 \mathrm{~ns}$ & $887.5 * * *$ & $4.9^{*}$ & $2.9 \mathrm{~ns}$ & $1.7 \mathrm{~ns}$ & $79.9^{* * *}$ \\
\hline CV (\%) & & 5.0 & 7.5 & 5.0 & 5.0 & 5.0 & 5.1 \\
\hline
\end{tabular}

Table 2. Continue.

\begin{tabular}{|c|c|c|c|c|c|c|c|c|}
\hline \multirow{3}{*}{ Sample No. } & \multirow{3}{*}{ Texture } & \multirow{3}{*}{$\begin{array}{l}\text { CEC } \\
\left(\mathrm{me} 100 \mathrm{~g}^{-1}\right)\end{array}$} & \multirow{2}{*}{\multicolumn{4}{|c|}{ EB (me.100 g ${ }^{-1}$ soil) }} & \multirow{3}{*}{$\begin{array}{l}\text { BS } \\
\% \\
\end{array}$} & \multirow[t]{3}{*}{ ESP } \\
\hline & & & & & & & & \\
\hline & & & $\mathbf{C a}$ & Mg & $\mathbf{K}$ & $\mathbf{N a}$ & & \\
\hline \multicolumn{9}{|c|}{ MUUNGANO (MAWEMAIRO/MATUFA) } \\
\hline $\mathrm{Mu}-\mathrm{P} 1$ & $\mathrm{CL}$ & $15.18 b$ & $15.50 \mathrm{~b}$ & $2.70 \mathrm{c}$ & $0.70 \mathrm{c}$ & $0.64 \mathrm{c}$ & $100 \mathrm{a}$ & $4.2 \mathrm{c}$ \\
\hline Mu-P2 & SCL & $16.37 \mathrm{~b}$ & $15.00 \mathrm{~b}$ & $4.20 \mathrm{~b}$ & $0.50 \mathrm{~d}$ & $0.79 \mathrm{~b}$ & $100 \mathrm{a}$ & $4.8 \mathrm{~b}$ \\
\hline Mu-P3 & SCL & $15.47 b$ & $12.10 \mathrm{c}$ & $2.60 \mathrm{c}$ & $3.29 \mathrm{a}$ & $0.60 \mathrm{c}$ & $100 \mathrm{a}$ & $3.9 \mathrm{c}$ \\
\hline Mu-P4 & $\mathrm{C}$ & $26.78 \mathrm{a}$ & $18.80 \mathrm{a}$ & $10.40 \mathrm{a}$ & $1.04 \mathrm{~b}$ & $1.58 \mathrm{a}$ & $100 \mathrm{a}$ & $5.9 \mathrm{a}$ \\
\hline \multicolumn{9}{|c|}{ One Way ANOVA (F-Statistics) } \\
\hline F-Value & F-Value & $163.5^{* * *}$ & $50.6 * * *$ & $898.8^{* * *}$ & $2692.7 * * *$ & $446.6 * * *$ & $0.0 \mathrm{~ns}$ & $56.9^{* * *}$ \\
\hline CV (\%) & & 4.1 & 4.4 & 4.3 & 3.1 & 4.2 & 4.3 & 4.3 \\
\hline \multicolumn{9}{|l|}{ MKOMBOZI } \\
\hline M-P1 & SL & $11.31 \mathrm{~b}$ & $16.0 \mathrm{a}$ & $0.7 \mathrm{~b}$ & $0.20 \mathrm{~b}$ & $1.23 b$ & $100 \mathrm{a}$ & $10.9 \mathrm{~b}$ \\
\hline M-P2 & SL-SCL & $14.58 \mathrm{a}$ & $17.4 \mathrm{a}$ & $1.3 \mathrm{a}$ & $0.86 \mathrm{a}$ & $1.73 \mathrm{a}$ & $100 \mathrm{a}$ & $11.9 \mathrm{a}$ \\
\hline \multicolumn{9}{|c|}{ One Way ANOVA (F-Statistics) } \\
\hline F-Value & & $58.9 * *$ & $7.5 \mathrm{~ns}$ & $252.7 * * *$ & $705.2 * * *$ & $98.3 * * *$ & $0.0 \mathrm{~ns}$ & $8.2^{*}$ \\
\hline CV (\%) & & 14.5 & 15.3 & 4.6 & 4.2 & 5.1 & 36.1 & 12.7 \\
\hline \multicolumn{9}{|c|}{ ENDAMAJEK (QASH } \\
\hline E-P1 & $\mathrm{C}$ & $29.76 \mathrm{a}$ & $20.2 \mathrm{a}$ & $13.3 \mathrm{a}$ & $3.62 \mathrm{c}$ & $1.55 \mathrm{a}$ & $100 \mathrm{a}$ & $5.2 \mathrm{~b}$ \\
\hline E-P2 & $\mathrm{C}$ & $18.45 b$ & $4.5 \mathrm{~b}$ & $3.8 \mathrm{c}$ & $5.48 \mathrm{a}$ & $0.45 \mathrm{c}$ & $100 \mathrm{a}$ & $2.4 \mathrm{c}$ \\
\hline E-P3 & $\mathrm{C}$ & $27.78 \mathrm{a}$ & $19.1 \mathrm{a}$ & $11.0 \mathrm{~b}$ & $4.93 \mathrm{~b}$ & $1.58 \mathrm{a}$ & $100 \mathrm{a}$ & $5.7 \mathrm{~b}$ \\
\hline E-Hi2 & SL- SCL & $6.55 \mathrm{c}$ & $4.1 \mathrm{~b}$ & $1.4 \mathrm{~d}$ & $0.47 \mathrm{~d}$ & $1.19 b$ & $100 \mathrm{a}$ & $18.2 \mathrm{a}$ \\
\hline \multicolumn{9}{|c|}{ One Way ANOVA (F-Statistics) } \\
\hline F-Value & & $264.6^{* * *}$ & $466.8^{* * *}$ & $492.4 * * *$ & $357.0 * * *$ & $203.6 * * *$ & $0.0 \mathrm{~ns}$ & $599.1 * * *$ \\
\hline CV (\%) & & 5.5 & 5.9 & 6.0 & 5.7 & 5.4 & 5.0 & 6.3 \\
\hline
\end{tabular}

*: significant at $P=.05 ; * * *$ : significant at $P=.001$; ns: not significantly different from each other; CV: Coefficient of variation. Values followed by dissimilar letters in the same column for each parameter are significantly different from each other at $P=.05$ according to Fischer Least significance difference (LSD). EC = Electrical Conductivity, $\mathrm{TN}=$ Total Nitrogen; $\mathrm{C} / \mathrm{N}=$ Carbon/Nitrogen ratio, Pav = Available Phosphorus; $\mathrm{K}=\mathrm{Potassium} ; \mathrm{Ca}=\mathrm{Calcium}$; $\mathrm{Mg}=\mathrm{Magnesium}$; $\mathrm{Na}=$ Sodium, $\mathrm{OC}=$ Organic Carbon; $\mathrm{CEC}=$ Cation Exchange Capacity; $\mathrm{BS}=$ Base Saturation, ESP = Exchangeable Sodium Percentage; SCL = Sand Clay Loam; CL = Clay Loam; C = Clay; CH: Chipogolo; MSAG: Msagali; Pa: Plain; Pi: Piedmont 
Table 3. Summary of the results of the Cation Ratios and Total Exchangeable bases in the top soil samples (0-30 cm).

\begin{tabular}{|c|c|c|c|c|c|}
\hline Mapping Unit & Texture & $\mathrm{Ca} / \mathrm{Mg}$ & $\mathbf{M g} / \mathrm{K}$ & K/TEB & TEB \\
\hline \multicolumn{6}{|l|}{ Muungano } \\
\hline $\mathrm{Mu}-\mathrm{P} 1$ & $\mathrm{CL}$ & $5.74 a$ & $3.86 \mathrm{c}$ & $0.04 \mathrm{~b}$ & $19.54 b$ \\
\hline Mu-P2 & SCL & $3.57 \mathrm{c}$ & $8.40 \mathrm{~b}$ & $0.02 \mathrm{c}$ & $20.49 b$ \\
\hline Mu-P3 & SCL & $4.65 b$ & $0.79 \mathrm{~d}$ & $0.18 \mathrm{a}$ & $18.59 \mathrm{~b}$ \\
\hline Mu-P4 & $\mathrm{C}$ & $1.81 \mathrm{~d}$ & $10.00 \mathrm{a}$ & $0.03 b c$ & $37.23 \mathrm{a}$ \\
\hline \multicolumn{6}{|c|}{ One Way ANOVA (F-Statistics) } \\
\hline F Value & & $190.8 * * *$ & $457.9 * * *$ & $773.5 * * *$ & $149.4 * * *$ \\
\hline CV $(\%)$ & & 5.3 & 5.9 & 7.0 & 5.3 \\
\hline \multicolumn{6}{|l|}{ Mkombozi } \\
\hline M-P1 & SL & $22.86 \mathrm{a}$ & $3.50 \mathrm{a}$ & $0.01 b$ & $18.13 b$ \\
\hline M-P2 & SL-SCL & $13.38 b$ & $1.51 \mathrm{~b}$ & $0.03 \mathrm{a}$ & $27.00 \mathrm{a}$ \\
\hline \multicolumn{6}{|c|}{ One Way ANOVA (F-Statistics) } \\
\hline F Value & & $153.5 * * *$ & $326.4 * * *$ & $460.5^{* * *}$ & $89.3 * * *$ \\
\hline CV $(\%)$ & & 5.2 & 5.4 & 5.6 & 5.1 \\
\hline \multicolumn{6}{|l|}{ Endamajek } \\
\hline E-P1 & $\mathrm{C}$ & $1.52 \mathrm{c}$ & $3.67 \mathrm{a}$ & $0.09 \mathrm{c}$ & $41.14 \mathrm{a}$ \\
\hline E-P2 & $\mathrm{C}$ & $1.20 \mathrm{~d}$ & $0.69 \mathrm{~d}$ & $0.39 \mathrm{a}$ & $14.23 \mathrm{c}$ \\
\hline E-P3 & $\mathrm{C}$ & $1.74 \mathrm{~b}$ & $2.23 \mathrm{c}$ & $0.13 b$ & $36.96 \mathrm{~b}$ \\
\hline E-Hi2 & SL-SCL & $2.93 a$ & $2.98 \mathrm{~b}$ & $0.07 \mathrm{~d}$ & $7.16 \mathrm{~d}$ \\
\hline \multicolumn{6}{|c|}{ One Way ANOVA (F-Statistics) } \\
\hline F-Value & & $178.1 * * *$ & $282.2 * * *$ & $585.3 * * *$ & $404.7 * * *$ \\
\hline $\mathrm{CV}(\%)$ & & 5.3 & 5.5 & 6.3 & 5.8 \\
\hline
\end{tabular}

***: significant at $P=.001 ; \mathrm{CV}$ : Coefficient of variation. Values followed by dissimilar letters in the same column for each parameter are significantly different from each other at $P=.05$ according to Fischer Least significance difference $(\mathrm{LSD}) . \mathrm{K}=$ Potassium; $\mathrm{Ca}=\mathrm{Calcium}$; $\mathrm{Mg}=\mathrm{Magnesium}$; $\mathrm{Na}=\mathrm{Sodium}$, TEB $=$ Total Exchangeable Bases, BS = Base Saturation; SCL = Sand Clay Loam; SL = Sand loam; CL= Clay Loam; C = Clay; E: Endamajek; M: Mkombozi; Mu: Muungano (Mawemairo/Matufa); P: Profile;

\subsection{Total Soil Organic Matter (OM)}

Results of the present study revealed that, Soil Organic Carbon (\% OC) of the top-soils in sites under study were generally very low $\left(4.0 \mathrm{~g} \mathrm{~kg}^{-1}\right)$ to medium $\left(19.1 \mathrm{~g} \mathrm{~kg}^{-1}\right)$ corresponding to OM of 6.9-32.9 $\mathrm{g} \mathrm{kg}^{-1}$ (Table 2). Since OM content was calculated from soil organic carbon [23], these indicators had the same trend. Results also added that, organic carbon in most of the profiles generally decreased with increasing soil depth although not systematic. In Muungano (Mu-P4), the OC was $12.5 \mathrm{~g} \mathrm{~kg}^{-1}$ in the $50 \mathrm{~cm}$ of soil depth, increased to $13.4 \mathrm{~g} \mathrm{~kg}^{-1}$ in the next $50 \mathrm{~cm}$ soil depth while decreased to $1.1 \mathrm{~g} \mathrm{~kg}^{-1}$ in the next $50 \mathrm{~cm}$ of soil depth. This also applied to M-Pal in Mkombozi. It is generally accepted that a threshold for OM in most soils is 34 $\mathrm{g} \mathrm{kg}^{-1}$ below which decline in soil quality is expected to occur [41]. Soil organic matter (OM) was below the proposed threshold values in all the sites under study, suggesting a decline in soil quality (Table 3). It is, therefore, apparent that there is a need to replenish the OM using resources such as crop residues and manure for maximum crop yields. Understanding the OM status before any development interventions are undertaken is of vital importance as it is extensively known to play a key role in the improvement of soil physical and chemical properties. These properties include structural stability, porosity, mineral elements availability (i.e. N, P and S); cation exchange capacity [35, 42, 43, 44, 45]; and soil moisture and nutrient holding capacity [14]. Soil organic matter has also been reported to have great impact on improving irrigation efficiency for sustainable land productivity; to enhance productivity and environmental quality; to reduce the severity and costs of natural phenomena, such as drought, flood, and disease; as well as to reduce atmospheric $\mathrm{CO}_{2}$ levels that contribute to climate change [46, 47, 48, 49].

\subsection{Total Nitrogen (TN)}

According to results of the present study regarding total nitrogen $(\mathrm{TN})$ status in the study areas was ranged 0.3 to 1.4 $\mathrm{g} \mathrm{kg}^{-1}$ (Tables 2, 4). According to [33] guidelines, the proposed value for most crops in Tanzania is $2 \mathrm{~g} \mathrm{~N} \mathrm{~kg}^{-1}$ soil. The results show that all the surveyed sites had total $\mathrm{N}$ below the threshold value $\left(<2 \mathrm{~g} \mathrm{~kg}^{-1}\right)$ and was rated as low and or very low (Tables 2, 4). The observed low $\mathrm{N}$ in these areas may be attributed to, amongst others, low OM content which is greatly influenced by microbial activity in the soil [50] and high soil $\mathrm{pH}$ which could lead to $\mathrm{N}$ loss through ammonia volatilisation [51]. In our study, soil samples with relatively higher $\mathrm{N}$ levels were obtained from the relatively organic enriched soils. So, any activity envisaged to improve the soil $\mathrm{pH}, \mathrm{OM}$ and microbial activities can, consequently, lead to an increase in the $\% \mathrm{~N}$ in the soil. Inadequate amounts of $\mathrm{N}$ in the soil are the primary factor that limits plant growth and development in many parts of the world $[52 ; 53]$ suggesting short- and long-term interventions. Practices such as choice of cropping systems involving legumes with ability to symbiotically fix $\mathrm{N}_{2}$ from the atmosphere, the use of artificial acidified nitrogen fertilisers, animal manure or composts are some of the means by which $\mathrm{N}$ input into the soil can be effected. 
Table 4. Soil fertility status for the selected schemes of Babati district.

\begin{tabular}{|c|c|c|c|c|c|c|c|c|c|c|c|c|c|}
\hline \multirow{2}{*}{ Soil fertility unit symbol } & \multirow[t]{2}{*}{ Texture } & \multirow{2}{*}{$\begin{array}{l}\mathrm{S} \\
\%\end{array}$} & \multicolumn{8}{|c|}{ Soil fertility rating } & \multicolumn{3}{|c|}{ Area } \\
\hline & & & pH & TN & $\mathbf{P}$ & $\mathbf{K}$ & $\mathrm{Ca}$ & Mg & OM & CEC & ESP & Ha & $\%$ \\
\hline \multicolumn{14}{|l|}{ Muungano } \\
\hline MU-Pa11 & CL & $<1$ & $\mathrm{~N}$ & $\mathrm{~L}$ & $\mathrm{~L}$ & M & $\mathrm{VH}$ & M & $\mathrm{L}$ & M & NS & 170 & 20 \\
\hline MU-Pa12 & SCL & $<1$ & MA & VL & $\mathrm{L}$ & M & VH & $\mathrm{H}$ & $\mathrm{L}$ & M & NS & 164 & 19 \\
\hline MU-Pa13 & $\mathrm{C}$ & $<1$ & MA & $\mathrm{L}$ & $\mathrm{H}$ & VH & VH & M & $\mathrm{L}$ & M & NS & 330 & 26 \\
\hline MU-Hi1 & SCL & $2-4$ & MA & $\mathrm{L}$ & $\mathrm{L}$ & $\mathrm{M}$ & $\mathrm{H}$ & $\mathrm{VH}$ & $\mathrm{L}$ & $\mathrm{H}$ & NS & 303 & 35 \\
\hline \multicolumn{13}{|l|}{ Gichameda } & 100 \\
\hline M-Pa1 & SL & $<1$ & SA & VL & $\mathrm{H}$ & $\mathrm{L}$ & $\mathrm{VH}$ & M & VL & $\mathrm{L}$ & MS & 501 & 66 \\
\hline M-Pa2 & SL-SCL & $<1$ & MA & $\mathrm{L}$ & $\mathrm{H}$ & $\mathrm{H}$ & $\mathrm{VH}$ & $\mathrm{H}$ & M & M & MS & 216 & 29 \\
\hline Mu-Hi1 & & & & & & & & & & & & 36 & 5 \\
\hline Total Area (ha) & & & & & & & & & & & & 753 & 100 \\
\hline \multicolumn{14}{|l|}{ Endamajek } \\
\hline E-Pa11 & $\mathrm{C}$ & $<1$ & MA & $\mathrm{L}$ & $\mathrm{M}$ & $\mathrm{VH}$ & $\mathrm{VH}$ & $\mathrm{VH}$ & M & $\mathrm{H}$ & NS & 531 & 31.8 \\
\hline E-Pa21 & $\mathrm{C}$ & $<1$ & MA & $\mathrm{L}$ & M & $\mathrm{VH}$ & $\mathrm{H}$ & $\mathrm{H}$ & M & M & NS & 400 & 23.9 \\
\hline E-Pa22 & $\mathrm{C}$ & $<1$ & MA & $\mathrm{L}$ & $\mathrm{M}$ & $\mathrm{VH}$ & $\mathrm{H}$ & $\mathrm{VH}$ & M & $\mathrm{H}$ & NS & 297 & 17.8 \\
\hline E-Hi2 & SL & $<5$ & $\mathrm{MiA}$ & $\mathrm{L}$ & $\mathrm{M}$ & $\mathrm{H}$ & $\mathrm{H}$ & $\mathrm{H}$ & M & $\mathrm{L}$ & SS & 444 & 26.6 \\
\hline Total Area (ha) & & & & & & & & & & & & 1,672 & 100.0 \\
\hline
\end{tabular}

Classification: According to NSS (1990) guidelines. $\mathrm{MU}=$ Muungano; $\mathrm{M}=$ Mkombozi; $\mathrm{E}=$ Endamajek; $\mathrm{Pa}=\mathrm{Plain} ; \mathrm{Pi}=$ Piedmont; $\mathrm{S}(\%)=\mathrm{Slope}$ percent; TN $=$ Total Nitrogen; $\mathrm{P}=$ Phosphorus; $\mathrm{K}=$ Potassium; $\mathrm{Ca}=$ Calcium; $\mathrm{Mg}=$ Magnesium; $\mathrm{OM}=$ Organic Matter; $\mathrm{CEC}=\mathrm{Cation}$ Exchange Capacity; $\mathrm{ESP}=$ Exchangeable Sodium Percentage; $\mathrm{SCL}=$ Sand Clay Loam; $\mathrm{CL}=$ Clay Loam; $\mathrm{C}=$ Clay; $\mathrm{N}=$ Neutral; MA = Moderately alkaline; $\mathrm{SA}=\mathrm{Slightly}$ alkaline; MiA $=$ Mildly alkaline; $\mathrm{M}=$ Medium; $\mathrm{VL}=$ Very low $\mathrm{L}=$ Low $\mathrm{H}=$ High; $\mathrm{VH}=$ Very High

\subsection{C/N Ratio}

Results of $\mathrm{C} / \mathrm{N}$ ratios in this study are shown in Tables 2 and 4 and ranged from 11 - 17 [33]. However, the most acceptable and favourable $\mathrm{C} / \mathrm{N}$ ratio to most soils is $8-13$. For adequate humification process, a $\mathrm{C} / \mathrm{N}$ of 10 is considered as optimal. The result shows that the $\mathrm{C} / \mathrm{N}$ ratio of most of the mapping units in the selected irrigation schemes was less than 15. These were rated as moderate to good quality organic matter $(\mathrm{OM})$. Such conditions are favourable for most plants growth due to the fact that immobilization in the soil is less than mineralization. In the mapping unit $\mathrm{Mu}-\mathrm{P} 2$, $\mathrm{C} / \mathrm{N}$ ratio is 17 , suggesting neutral conditions, that is, mineralization is equal to immobilization. The data also shows nitrogen $(\mathrm{N})$ to be low to very low suggesting that in order to avoid leaching caused by rainfall or irrigation, ammoniocal form of $\mathrm{N}$ should be included in the fertiliser management program as it has better resistance to leaching. For example, a $\mathrm{C} / \mathrm{N}$ ratio of more than 23 have been shown to favour slow degradation of residues by the associated micro-organisms, higher immobilisation effects and limited $\mathrm{N}$ in the soil leading to reduced crop yields $[54,55,56]$. The status of the $\mathrm{C} / \mathrm{N}$ ratio in the surveyed areas suggests ideal conditions for plant growth, since in such situations mineralisation in the soil is greater than immobilisation.

\subsection{Available Phosphorus (AP)}

Most of soils in Muungano have $(P \leq 0.05)$ low available phosphorus (AP). Results have shown that the available $\mathrm{P}$ was ranged from $1.7-23.72 \mathrm{mg} \mathrm{kg}^{-1}$ and rated as low and high. Of the total area surveyed, $65.9 \%$ was rated as low available $\mathrm{P}$ (Mu-P1; Mu-P2 and Mu-Hi1) and 33.1\% as high available $\mathrm{P}$ (Mu-P3). The amount of available $\mathrm{P}$ in Mkombozi differed significantly $(P \leq 0.05)$ between the two mapping units surveyed. As shown in Tables (2) and (4), available $\mathrm{P}$ in the two mapping units ranged from 22.38 to $33.34 \mathrm{mg} \mathrm{kg}^{-1}$ and was rated as high [33]. Referring the Endamajek, Av. P differed markedly across the mapping units. This was rated as medium and ranged from 5.1 to 9.86 $\mathrm{mg} \mathrm{kg}^{-1}$ soil. An average P level of more than $7 \mathrm{mg} \mathrm{kg}^{-1}$ is considered optimal below which $\mathrm{P}$ - deficiency symptoms are likely to occur in most crops [33]. The observed low $\mathrm{P}$ in Muungano (Mu-P1, Mu-P2 and $\mathrm{Mu}-\mathrm{Hi} 2$ ) and medium values of $P$ in all the mapping units in Endamajek could partly be attributed to fixation into unavailable forms due to high soil $\mathrm{pH}$ especially in areas such as Muungano and Endamajek (Tables 2, 3). For example, in alkaline soils, calcium phosphates $\left(\mathrm{Ca}_{3}\left(\mathrm{PO}_{4}\right)_{2}\right.$ are less soluble, hence high $\mathrm{P}$ retention capacity and consequently low $\mathrm{P}$ availability [57]. Under such soil alkaline condition, phosphate fertilizer can be applied in bands with fertilizers which generate an ionized form of ammonia $\left(\mathrm{NH}_{4}{ }^{+}\right)$. The generated $\mathrm{NH}_{4}{ }^{+}$ion will allow slight acidification of the soil adjacent to the fertilizer band thereby creating favourable condition for $\mathrm{P}$ availability to plants. Similarly, compound nutrient fertilizer granules that contain the N, P, and sometimes elemental S can be applied into alkaline soils. Consequently, the soil adjacent to the granule will be acidified slightly and allow enhanced $\mathrm{P}$ uptake when the crop roots intercept the granules. Overall, future plans should include soluble $\mathrm{P}$ application (i.e. TSP, DAP or MAP) in these soils in order to moderate the P levels in the respective soils.

\subsection{Exchangeable Bases (K, $\mathrm{Mg}, \mathrm{Ca})$}

\subsubsection{Exchangeable $\mathrm{Ca}^{+}$}

The exchangeable $\mathrm{Ca}^{2+}$ in the topsoil of the Muungano (Mawemairo/Matufa) study area were significantly $(P \leq$ 0.05 ) different from each other and ranged from 12.1 to 18.8 
cmol $(+) \mathrm{kg}^{-1}$ soil in $\mathrm{Mu}-\mathrm{P} 3$ and Mu-P4 respectively. The data showed that of the total area, $66 \%$ was rated as very high and $34 \%$ as high (Tables 2, 4). Exchangeable $\mathrm{Ca}$ in the top soils of Mkombozi scheme was not $(P \leq 0.05)$ different from each other and ranged from $16.0 \mathrm{cmol}(+) \mathrm{kg}^{-1}$ (i.e. M-P1) to 17.4 cmol (+) $\mathrm{kg}^{-1}$ (i.e. M-P2). These were rated as very high. Results showed that exchangeable $\mathrm{Ca}$ in the top soils of Endamajek scheme were $(P \leq 0.05)$ different and ranged from $4.1 \mathrm{cmol}(+) \mathrm{kg}^{-1}$ in E-Hi2 to $20.2 \mathrm{cmol}(+) \mathrm{kg}^{-1}$ in E-P1 rated as high to very high respectively. However, exchangeable $\mathrm{Ca}$ in E-P1 and E-P3 representing 50\% of the surveyed area was greater $(P \leq 0.05)$ compared with that observed in E-P2 and E-Hi2 (Tables 2, 4). [65] Proposed that in most crops, the recommended threshold level of $\mathrm{Ca}^{2+}$ is 5 cmol $(+) \mathrm{kg}^{-1}$. Calcium deficiency occurs frequently in a range of crops when exchangeable $\mathrm{Ca}$ concentration is less than $1 \mathrm{cmol}(+) \mathrm{kg}^{-1}[66 ; 67]$. It is generally acknowledged that field conditions that limit $\mathrm{Ca}^{2+}$ uptake produce lower crop yields than crops grown with adequate $\mathrm{Ca}^{2+}[68 ; 69 ; 70$; 71]. The high to very high levels of $\mathrm{Ca}^{2+}$ in the study areas indicates lower bondage of $\mathrm{Ca}^{2+}$ to $\mathrm{P}$ at relatively lower soil reactions (Tables 2,4 ).

\subsubsection{Exchangeable $\mathrm{Mg}^{2+}$}

These results also showed that $\mathrm{Mg}^{2+}$ content in the topsoil of Munngano (Mawemairo/Matufa) study area ranged from

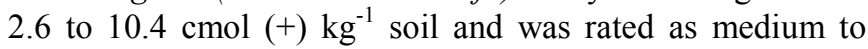
very high. In this area, $\mathrm{Mg}$ content in the different mapping units was significantly $(P \leq 0.05)$ different from each other. The data showed $\mathrm{Mg}$ was medium in $51.7 \%$, high in $17.0 \%$ and very high in $31.3 \%$ of the total area surveyed (Table 2, 4). In Mkombozi, top soil Mg contents ranged from 0.7 to 1.3 cmol $(+) \mathrm{kg}^{-1}$ soil rated as medium to high. It was observed that $\mathrm{Mg}$ levels in M-P2 in $33 \%$ of the area were $(P \leq 0.05)$ greater compared with M-P1 mapping unit which was $67 \%$ of the area surveyed (Table 2, 4). In Endamajek, Mg levels were $(P \leq 0.05)$ different between mapping units. The data showed that $\mathrm{Mg}$ contents ranged from $1.4 \mathrm{cmol}(+) \mathrm{kg}^{-1}$ in E$\mathrm{Hi} 2$ to $13.3 \mathrm{cmol}(+) \mathrm{kg}^{-1}$ in E-P1. These were rated as high in $50 \%$ of the surveyed area (E-P2 and E-Hi2) and very high in $50 \%$ of the surveyed area (E-P1 and E-P3). The recommended value of $\mathrm{Mg}^{2+}$ in most crops is $2 \mathrm{cmol}(+) \mathrm{kg}^{-1}$ [60]. The observed levels of $\mathrm{Mg}^{2+}$ suggest that these areas have sufficient $\mathrm{Mg}^{2+}$ supplies for crop growth. $\mathrm{Mg}$ is required by a large number of enzymes involved in energy transfer, particularly those utilizing ATP; a constituent of the chlorophyll molecule; is required for the normal structural development of the chloroplast; as well as other organelles such as the mitochondrion [61, 62, 63, 64]. Thus, it is expected that $\mathrm{Mg}$ levels would be maintained or improved so as to avoid damaging effects on photosynthesis and respiration that would lead to poor crop yields.

\subsubsection{Exchangeable $\mathrm{K}^{+}$}

In Muungano study area, significant differences $(P \leq 0.05)$ were observed between the mapping units for potassium $(\mathrm{K})$ levels in the soil which ranged 0.50 to $3.29 \mathrm{cmol}(+) \mathrm{kg}^{-1}$ soil (Table 3$)$. These were rated as $(P \leq 0.05)$ medium in $65.9 \%$ (i.e. Mu-P1, Mu-P2, Mu-P4) and $(P \leq 0.05)$ very high in $34.1 \%$ (i.e. Mu-P3) of the total area (i.e. 967 ha) assessed. Although $\mathrm{K}$ values in $\mathrm{Mu}-\mathrm{P} 1, \mathrm{Mu}-\mathrm{P} 2$ and $\mathrm{Mu}-\mathrm{P} 4$ were rated as medium, Mu-P4 had $(P \leq 0.05)$ higher value compared with others. In Gichameda, K levels were significantly $(P \leq$ 0.05 ) different between the study areas (Table 2). Results showed that $\mathrm{K}$ ranged from 0.20 to $0.86 \mathrm{cmol}(+) \mathrm{kg}^{-1}$ soil, and was rated as low in 67\% (M-P1) and high in 33\% (M-P2) of the total area (i.e. 753 ha) surveyed. Comparatively, M-P2 has significantly $(P \leq 0.05)$ greater $\mathrm{K}$ values compared with M-P1 (Tables 2). In Endamajek, $K$ values ranged 0.47 to 5.48 cmol $(+) \mathrm{kg}^{-1}$ soil, and was rated as $(P \leq 0.05)$ high in $27 \%$ to $(P \leq 0.05)$ very high in $73 \%$ of the total area (i.e. 1,672 ha) assessed (Tables 2, 4). Comparatively, the data show that EP3 has $(P \leq 0.05)$ greater $\mathrm{K}$ levels compared with other mapping units. However, the $(P \leq 0.05)$ lowest $\mathrm{K}$ value was observed at E-Hi2 mapping unit. It is generally accepted that response to $\mathrm{K}$ fertilisers is likely when a soil has an exchangeable $\mathrm{K}$ value of less than $0.2 \mathrm{cmol}(+) \mathrm{kg}^{-1}$ soil and unlikely when it is above $0.4 \mathrm{cmol}(+) \mathrm{kg}^{-1}$ soil $[33 ; 58]$. Based on the critical concentrations of exchangeable $\mathrm{K}$ values of 0.2 to $0.4 \mathrm{cmol}(+) \mathrm{kg}^{-1}$ soil, the data suggests that $\mathrm{K}$ is not a limiting mineral element to crop productivity in the study area $[33,59]$.

\subsection{Cation Exchange Capacity}

Results of the present study showed that there was significant $(P \leq 0.05)$ difference in the cation exchange capacity (CEC) in Muungano soils which ranged 15.2 to 26.8 cmol kg-1 and rated as medium to high (Tables 2, 4) [33]. Several studies have shown that soils with CEC values between 6 to $12 \mathrm{cmol} \mathrm{kg}^{-1}$ are poor in exchangeable bases [33]. Of the total surveyed area in Muungano, $68.7 \%$ was rated as having medium $\mathrm{CEC}$ and $31.3 \%$ as having High CEC. CEC of top soils in Mkombozi $(P \leq 0.05)$ differed between M-P1 and M-P2 fields surveyed. For example, CEC was highest in M-P2 (14.6 $\left.\mathrm{cmol} \mathrm{kg}^{-1}\right)$ and lowest in M-P1 $\left(11.3 \mathrm{cmol} \mathrm{kg}^{-1}\right)$ (Tables 2, 4). These were rated as high and low respectively. Low CEC was observed in $67 \%$ and high in $33 \%$ of the total area assessed. Similarly, CEC in Endamajek $(P \leq 0.05)$ differed between the areas surveyed with E-P1 and E-P3 being greater compared to E-P2 and E-P4. The data show that E-P1 (29.8 $\left.\mathrm{cmol} \mathrm{kg}^{-1}\right)$ and E-P3 (i.e. $27.8 \mathrm{cmol} \mathrm{kg}^{-}$ ${ }^{1}$ ) found in $50 \%$ of the total area assessed were highest compared with E-P2 (i.e. $18.5 \mathrm{cmol} \mathrm{kg}^{-1}$ ) and $6.55 \mathrm{cmol} \mathrm{kg}^{-1}$ found in $24 \%$ and $27 \%$ of the total area assessed respectively (see Table 3, 5). According to [72], soils with low CEC are typically weathered with a low ability to support plant growth with adequate mineral element such as $\mathrm{Ca}$. It is generally accepted that SOM is responsible for $25-90 \%$ of the total CEC of surface horizons of mineral soils [73; 74]. The low to medium CEC found in some areas in this study could be related to low SOM (Tables 2, 4). The low CEC values in soils have also been implicated with low yield in most agricultural soils [72]. Any intervention such as applying both manure and the required amount of fertiliser with the aim of improving the CEC of the soil is 
recommended. By doing so, humus content of the soil will increase and, consequently, improve the CEC that may lead to better retention of mineral elements in the soil.

\subsection{Exchangeable Sodium (Na) or Exchangeable Sodium Percentage (ESP)}

The exchangeable sodium $\left(\mathrm{Na}^{+}\right)$in Muungano differed $(P$ $\leq 0.05)$ markedly between the mapping units assessed and ranged from $0.60(\mathrm{Mu}-\mathrm{P} 3)$ to $1.58 \mathrm{cmol}(+) \mathrm{kg}^{-1}$ soil $(\mathrm{Mu}-$ Hi1). These were rated as medium to high and occupies $51.7 \%$ and $48.3 \%$ of the total area assessed respectively. The corresponding ESP values ranged from 4.2 to $5.6 \%$ (Tables 2, 4) rated as non-sodic. In Mkombozi, $\mathrm{Na}^{+}$values ranged markedly from 1.23 to $1.73 \mathrm{cmol}(+) \mathrm{kg}^{-1}$ soil rated as high. These correspond to ESP values which ranged from 10.9 to $11.9 \%$ rated as moderately sodic. The $\mathrm{Na}$ values measured in Endamajek showed significant $(P \leq 0.05)$ differences across different mapping units surveyed and varied from 0.45 to $1.58 \mathrm{cmol}(+) \mathrm{kg}^{-1}$ soil. Of the total area surveyed, $76 \%$ was rated as of high $\mathrm{Na}$ and $24 \%$ as of moderate $\mathrm{Na}$ values. The corresponding ESP values also differed markedly and ranged from 2.4 and $18.2 \%$ respectively. Of the total area assessed, $56 \%$ were non-sodic, $18 \%$ as slightly sodic and $27 \%$ as strongly sodic. The critical values of ESP above which most crops are affected are established at 15 [75]. The medium to high $\mathrm{Na}$ or slightly sodic to very strongly sodic status observed in this study may probably be related to high evaporation, poor management of irrigation water, lack of drainage systems and low $\mathrm{Ca}^{2+}$ due to high $\mathrm{Na}^{+}$ concentrations in the exchange complex (Tables 2, 4). Higher $\mathrm{Na}^{+}$levels in the soil is associated with decline in net photosynthesis; energy losses for salt exclusion mechanisms; greater decrease in mineral elements uptake; poor $\mathrm{NO}_{3}{ }^{-}$ assimilation required for plant growth; inhibition of vital enzymes and competition with $\mathrm{K}^{+}[76,77,78$, 79]. The excessive $\mathrm{Na}^{+}$in the soil is likely to cause reduced plant growth and development, thus, decreased crop yields [80, 81, $82,83]$. Our results suggest that such sodic soils may require appropriate amendments such as farm yard manure (FYM) and/or gypsum to reduce the concentration of $\mathrm{Na}^{+}$on the exchange complex, thereafter followed by leaching to replace the soluble $\mathrm{Na}^{+}$on the soil colloid, through irrigation or rain water $[84 ; 2]$ and use of acidifying fertilisers such as sulphate of ammonia to lower the soil $\mathrm{pH}$. Successful results on the use of locally available soil ameliorants, such as gypsum $\left(\mathrm{CaSO}_{4} \cdot 2 \mathrm{H}_{2} \mathrm{O}\right)$ as a $\mathrm{Ca}^{2+}$ source and/or organic manure, has been reported in northern Tanzania [2].

\subsection{Cation Ratios}

The ratios of $\mathrm{Ca}: \mathrm{Mg}, \mathrm{Mg}: \mathrm{K}$ and $\mathrm{K}$ : TEB in Muungano are shown in Table (3). Results indicated that $\mathrm{Ca}: \mathrm{Mg}$ ratios in the mapping units surveyed were significantly $(P \leq 0.05)$ different and they ranged 1.81 in $\mathrm{Mu}-\mathrm{P} 4$ to 5.74 in $\mathrm{Mu}-\mathrm{P} 1$. The data also added that Mu-P1 had $(P \leq 0.05)$ greater $\mathrm{Ca}$ : $\mathrm{Mg}$ ratios compared with others, whereas $\mathrm{Mu}-\mathrm{P} 4$ scored the lowest ratios. Similarly, $\mathrm{Mg}$ : K ratio ranged 0.79 in $\mathrm{Mu}-\mathrm{P} 3$ to
10.0 Mu-P4 which was significantly $(P \leq 0.05)$ greater compared with other mapping units. Likewise, the $(P \leq 0.05)$ highest $\mathrm{K}$ : TEB ratio was recorded in $\mathrm{Mu}-\mathrm{P} 3$ compared with $\mathrm{Mu}-\mathrm{P} 2$. These values however, ranged from 0.02 to 0.18 . The TEB was significantly $(P \leq 0.05)$ different between the areas surveyed. Results showed that the lowest value (18.59) was recorded in $\mathrm{Mu}-\mathrm{P} 3$ while, $\mathrm{Mu}-\mathrm{P} 4$ scored the highest value (37.23). On the other hand, no significant differences were observed in TEB in mapping units under study $(\mathrm{Mu}-\mathrm{P} 1, \mathrm{Mu}-$ $\mathrm{P} 2$ and $\mathrm{Mu}-\mathrm{P} 3$ ).

The ratios of $\mathrm{Ca}: \mathrm{Mg}, \mathrm{Mg}: \mathrm{K}$, and $\mathrm{K}$ : TEB in Mkombozi were markedly different between the surveyed areas (see Table 3). For example, $\mathrm{Ca}: \mathrm{Mg}$ ratio ranged 13.38 in $\mathrm{M}-\mathrm{P} 2$ to 22.86 in $\mathrm{M}-\mathrm{P} 1$ which was the greatest $(P \leq 0.05)$ ratio as compared with M-P2. Results also showed that $\mathrm{Mg}$ : K ratio ranged 3.50 in $\mathrm{M}-\mathrm{P} 1$ to 1.51 in $\mathrm{M}-\mathrm{P} 2$ which was significantly lower $(P \leq 0.05)$ compared with $\mathrm{M}-\mathrm{P} 1$. Both of $\mathrm{K}$ : TEB ratio and TEB were recorded $(P \leq 0.05)$ the lowest ratio $(0.01$ to 0.03 and 18.13 to 27.00$)$ respectively in M-P1 as compared with M-P2.

Ca: $\mathrm{Mg}, \mathrm{Mg}: \mathrm{K}, \mathrm{K}$ : TEB ratios and TEB in Endamajek mapping units was significantly $(P \leq 0.05)$ different (see Table 4). The data showed that $\mathrm{Ca}: \mathrm{Mg}$ ratios ranged 1.20 in E-P2 to 2.93 in E-Hi2 which was $(P \leq 0.05)$ greater compared with other mapping units. It was also observed that $\mathrm{Mg}$ : $\mathrm{K}$ ranged between 0.69 in E-P2 to 3.67 in E-P1 it was significantly higher compared with other mapping units. K: TEB ratio ranged 0.07 in E-Hi2 to 0.39 in E-P2 which was markedly greater compared with other mapping units assessed. It was observed that TEB in the surveyed areas ranged 7.16 in $\mathrm{E}-\mathrm{Hi} 2$ to 41.14 in $\mathrm{E}-\mathrm{P} 1$ which was $(\mathrm{P} \leq 0.05)$ higher compared with the rest of the mapping units.

According to the established guidelines [33; 85], the recommended optimum ratio of $\mathrm{Mg}$ : $\mathrm{K}$ for most crops is $1-4$. Based on these results $51.7 \%$ of the surveyed area in Muungano, $100 \%$ in Mkombozi and $76 \%$ in Endamajek have values within the critical range suggesting favourable conditions for crop growth. The remaining areas have $\mathrm{Mg}$ : $\mathrm{K}$ ratios outside the critical range probably suggesting unfavourable conditions for crop growth. However, in areas where $\mathrm{K}$ was high, $\mathrm{Mg}$ was low and vice versa, suggests that these mineral elements are antagonistic. Research has indicated that the $\mathrm{Ca}$ : $\mathrm{Mg}$ ratio of 3 - 5 in the topsoil [33] is optimal for most crops. Based on this critical range, our data suggests less favourable conditions for most crops in all the surveyed areas except for $51.1 \%$ of the surveyed areas in Muungano (i.e. Mu-P2 and Mu-P3). The remaining surveyed areas in Mkombozi and Endamajek were either too high or too low. The availability of mineral elements for uptake by plants depends not only upon absolute levels but also on relative amounts of individual elements. It has been suggested that the optimal cation ratio for the growth of most crops in the tropical area is equal to $12.7: 3: 1$ for $\mathrm{Ca}: \mathrm{Mg}: \mathrm{K}$ respectively [33]. Although the general trend for $\mathrm{Ca}: \mathrm{Mg}: \mathrm{K}$ doesn't indicate a good ratio in relation to the established standards, the individual nutrient ratios are more important i.e. $\mathrm{Ca}: \mathrm{Mg}$; $\mathrm{Mg}$ : $\mathrm{K}$ and $\mathrm{K}$ : TEB. Research has also indicated 
that the K: TEB ratio of less than $2 \%$ is sub-optimal and may limit crop production [33]. Our results concluded that with the exception of $67 \%$ of the surveyed areas in Mkombozi (i.e. M-P1), the rest of the surveyed areas in Muungano and Endamajek have optimal values suggesting optimal conditions for plant growth. The less favourable conditions observed in Mkombozi (i.e. M-P1) suggest that plants would probably respond to the addition of $\mathrm{Ca}$ or $\mathrm{Mg}$ in such areas.

\section{Conclusion}

In conclusion, the results of the present study provide soil fertility status in the selected irrigation schemes. Data also suggest that soil indicators such as $\mathrm{pH}, \mathrm{TN}, \mathrm{P}$ and $\mathrm{OM}$ are the major soil fertility constraints to crop production in the area followed by CEC. This information could be incorporated in the soil fertility, salinity and/or sodicity management in Tanzania, thus, contributing significantly in the efficient utilisation of land resources in the study areas.

\section{Acknowledgements}

This study was supported by the Participatory Irrigation Development Programme (PIDP), Babati District, Manyara Region, Tanzania and the National Irrigation Commission, Dar es Salaam, Tanzania.

\section{References}

[1] Ngailo, JA, Wickama, JM, Nyaki, AS and Kaswamila, AL. Nutrient flow analysis for selected farming systems in the Northern Tanzania: The case of Mbulu, Moshi Rural and Lushoto Districts (pp 49-64). In: Soil and Nutrient management in sub-Saharan Africa in support of the soil fertility initiative. Pp.376; 1999.

[2] Makoi, JHJR and Ndakidemi, PA. Reclamation of sodic soils in northern Tanzania, using locally available organic and inorganic resources. Afr. J. Biotechnol. 16 (6):1926-1931; 2007.

[3] Mokwunye, AU, de Jager, A, and Smaling, EMA. Restoring and maintaining the productivity of West African soils: Key to sustainable development. Misc. fertilizer stud 14, Int. Dev. Central Africa, Lome, Togo; 1996.

[4] Sanchez, PA. Soil fertility and hunger in Africa. Sci. 295: 2019-2020; 2002.

[5] Mowo, JG, Janssen, BH, Oenema, O, German, LA, Mrema, JP, Shemdoe, RS. Soil fertility evaluation and management by smallholder farmer communities in northern Tanzania. Agriculture, Ecosyst \& Environ. 116 (1-2): 47-59; 2006.

[6] RLDC. Rural Livelihood Development Company, Rice Sector Strategy: Improving rice profitability through increased productivity and better marketing focusing on Tanzania's Central Corridor, Pp 34; November, 2009.

[7] Scoones, I. Dynamics and Diversity: Soil Fertility and Farming Livelihoods in Africa: Case Studies from Ethiopia, Mali, and Zimbambwe, Earthscan Publications Ltd., London, pp 244; 2001.
[8] Hellin, J. From soil erosion to soil quality. LEISA Mag. Low External Input Sustain Agric. 19 (4); 2003.

[9] Ndakidemi, PA and Semoka, JMR. Soil fertility in Western Usambara Mountains, Northern Tanzania. Pedosphere. 16 (2): 237-244; 2006.

[10] Defoer, T, Budelman, A (Eds.). Managing Soil Fertility in the Tropics. A Resource Guide for Participatory Learning and Action Research. KIT Publishers, Amsterdam; 2000.

[11] Lyamchai, CJ, Mowo, JG, Wickama, JM. Managing new working relationships: partnership and networking. In: AHI Regional Conference, Nairobi; 2004.

[12] Oue'draogo, E. Soil quality improvement for crop production in semi arid West Africa. PhD Thesis, Wageningen University, Wageningen; 2004.

[13] Sa1"dou, A, Kuyper, TW, Kossou, DK, Tossou, R, Richards, P. Sustainable soil fertility management in Benin: learning from farmers. NJAS-Wageningen. J Life Sci. 52: 349-369; 2004.

[14] Monreal, CM, Dinel, H, Schnitzer, M, Gamble, DS, Biederbeck, VO. Impact of carbon sequestration on functional indicators of soil quality as influenced by management in sustainable agriculture. P. 435-457. In: Lal R et al. (eds.) Soil processes and the carbon cycle, Lewis Publ., CRC Press, Roca balton, FL; 1997.

[15] Brady, NC, Weil, RR. Nature and Properties of Soils. $13^{\text {th }}$ Edition. With permission of Pearson Education, Inc., Upper Saddle River, New Jersey; 2002.

[16] NSCA. National Sample Census of Agriculture Small Holder Agriculture Volume II: Crop Sector - National Report (2007/2008); 2012.

[17] United State Department of Agriculture. Soil Taxonomy. A basic system of soil classification for making and interpreting soil surveys. Agricultural Handbook No. 436. Washington D. C. pp. $754 ; 1975$.

[18] Muchena, FM and Kiome, RM The role of soil science in agricultural development in East Africa. Geoderma. 67: 141$157 ; 1995$.

[19] Köppen, W. Dle Klirnate der Erde. Walter de Gruyter, Berlin; 1923.

[20] Makoi, JHJR. Soil Fertility assessment for irrigation in the selected schemes of Mbulu District. In: United Republic of Tanzania, Ministry of Agriculture and Food Security, Participatory Irrigation Development Programme. ZITS, Moshi, Kilimanjaro; 2003.

[21] Day, PR. Particle fraction and particle size analysis. In: Black CA et al. (Eds). Methods of soil analysis. Part 2. American Society of Agronomy, Madison. Pp. 545-567; 1965.

[22] Allison, E. Organic carbom. In: Black CA et al. (eds). Methods of soil analysis. Part 2. American Society of Agronomy, Madison. Pp.1367-1378; 1965.

[23] Walkley, A, Black, A. Determination of organic matter. Soil Sci. 37:29-38; 1934.

[24] Peech, M. Hydrogen ion activity. In: Black CA et al. (Eds). Methods of soil analysis. Part 2. American Society of Agronomy, Madison. Pp. 914-926; 1965. 
[25] Bremner, JM. Total nitrogen. In: Black CA et al. (eds). Methods of soil analysis. Part 2. American Society of Agronomy, Madison. Pp. 1149-1178; 1965.

[26] Chapman, HD. Cation exchange capacity. In: Black CA et al. (Eds). Methods of soil analysis. Part 2. American Society of Agronomy, Madison. Pp. 891-901; 1965.

[27] Polemio, M, Rhoades, JD. Determining cation exchange capacity: A new procedure for calcareous and gypsiferous soils. Soil Sci. Soc. Am. J. 41. 524-528; 1977.

[28] Hesse, PR. A Text Book of Soil Chemistry Analysis. John Murray Ltd. London. Pp. 120-309;1971.

[29] Piper, CS. Soil and Plant Analysis. University of Adelaide; 1942.

[30] Rodriguez, JB, Self, JR and Soltanpour, NP. Optimal conditions for phosphorous analysis by the ascorbic acidmolybdenum blue method. Soil Sci Soc Am J. 58:866-870; 1994.

[31] Murphy, J, and Riley, JP. A modified single solution method for determination of phosphates in natural waters. Anal Chim Acta. 27:31-36; 1962.

[32] Page, AL, Miller, RH, Keeney, DR. eds. Methods of Soil Analysis, Part 2: Chemical and Microbiological Properties, 2nd ed.: American Society of Agronomy, Madison, WI. 1982.

[33] NSS. Laboratory procedures for routine soil analysis, $3^{\text {rd }}$ ed. Ministry of Agriculture and Livestock Development, National Soil Service (NSS), ARI, Mlingano;1990.

[34] Schmidt, EL. Nitrification in Soil. In: Stevenson, F. J. (Ed), Nitrogen in Agricultural Soils. American Society of Agronomy, Madison, WI, pp. 253-288. ISBN 0891180702; 1982.

[35] Sanchez, PA, Palm, CA, Boul, SW. Fertility capability classification: A tool to help assess soil quality in the tropics. Geoderma. 114:157-185; 2003.

[36] Page, AL, Chang, AC, Adriano, DC. Deficiencies and toxicities of trace elements. Agricultural Salinity Assessment and Management, Chapter 7, ASCE Manuals and Reports on Eng. Practice No. 71, ASCE, pp.138-160; 1990.

[37] Foy, CD. Soil chemical factors limiting plant root growth. Adv Soil Sci. 19:97-131; 1992.

[38] Makoi, JHJR, Ndakidemi, PA. The agronomic potential of vesicular arbuscular mycorrhiza (VAM) in cereals- legume mixtures in Africa. Afr. J. Microbiol. Res. 3: 664-675; 2009.

[39] Kauffman, MD. The effect of soil acidity and lime placement on root growth and yield of winter wheat and alfalfa. Ph. D. Diss. Oregon state Univ., Corvallis. Diss. Abstr. 37B, 7, pp. 3192-3193; 1977.

[40] Adams, F. Crop response to lime in the Southern United States. In: Adams, F. (Ed.), Soil Acidity and Liming, second ed. Agronomy no. 12, ASA, CSSA, SSSA, WI, pp. 211-265; 1984.

[41] Loveland, P, Webb, J. Is there a critical level of organic matter in the agricultural soils of temperate regions: a review. Soil and Tillage Res. 70(1):1-18; 2003.

[42] Roscoe, R, Buurman P, Velthorst EJ, Vasconcellos CA. Soil organic matter dynamics in density and particle size fractions as revealed by the $13 \mathrm{C} / 12 \mathrm{C}$ isotopic ratio in a Cerrado's oxisol. Geoderma. 104:185-202; 2001.

[43] Kockba, M, Ritvo, G, Avinimeleck, Y. The effect municipal solid waste compost (MSW) on the replacement of sodium in sodic soil models. Soil Sci. 169: 567-572; 2004.

[44] Ferreras, L, Gomez, E, Toresani, S, Firpo, I, Rotondo, R. Effect of organic amendments on some physical, chemical and biological properties in a horticultural soil. Bioresource Tech. 97 (4): 635-640; 2006.

[45] Flavel, TC, Murphy, DV. Carbon and Nitrogen mineralization rates after application of organic amendments to the soil. J Environ Quality. 35: 183-193; 2006.

[46] Doran, J. Building soil quality. In: Proceedings of the 1995 Conservation Workshop on Opportunities and Challenges in Sustainable Agriculture. Red Deer, Alta., Canada, Alberta Conservation Tillage Society and Alberta Agriculture Conservation, Development Branch, pp. 151-158; 1995.

[47] Drinkwater, L. E., Letourneau, D. K., Workneh, F., van Bruggen, A. H. C., Shennan, C., Fundamental differences between conventional and organic tomato agroecosystems in California. Ecol. Appl. 5, 1098-1112; 1995.

[48] Shepherd, MA, Harrison, R, Webb, J. Managing soil organic matter - implications for soil structure on organic farms, Soil Use and Management 18 (s1): 284-292; 2006.

[49] Stamatiadis, S., Werner, M., Buchanan, M. Field assessment of soil quality as affected by compost and fertilizer application in a broccoli field (San Benito County, California). Appl. Soil Ecol. 12, 217-225;1999.

[50] Facelli, JM, Pickett, STA. Plant litter. Its dynamics and effects on plant community structure. Bot Rev. 57: 1-32; 1991.

[51] Rao, DLN and Batra, L. Ammonia volatilization from applied nitrogen in alkali soils. Plant Soil. 70(2): 219-228; 1983.

[52] Vermeer, JG, Berendse, F. The relationship between nutrient availability, shoot biomass and species richness in grassland and wetland communities. Vegetation. 53: 121-126; 1983.

[53] Tilman, GD. Plant dominance along an experimental nutrient gradient. Ecol. 65: 1445-1453; 1984.

[54] Goma, HC. Potential for changing traditional soil fertility management systems in the wet miombo woodlands of Zambia: the chitemene and fundikila systems: In: Gichuru, MP, Bationo, A, Bekunda, MA, Goma, HC, Mafongoya PL, Mugendi, DN, Murwira, HK, Nandwa, SM, Nyathi, P, Swift, MJ (eds). 2003. Soil fertility management in Africa: a regional perspective. pp 187-218; 2003.

[55] Eiland, F, Klamer, M, Lind, AM, Leth, M, Baath, E. Influence of initial $\mathrm{C} / \mathrm{N}$ ratio on chemical and microbial composition during long term composing of straw. Microbial Ecol. 41:272$280 ; 2001$.

[56] Uriyo, AP, Mongi, HO, Chowdhury, MS, Sing, BR and Semoka, JMR. Introductory Soil Science. Tanzania Publishing House, Dar es Salaam. pp 232; 1979.

[57] Hassett, JJ and Banwart, WL. Soils and their environment. Prentice Hall, Englewood, New Jersey. Pp.424; 1992.

[58] Anderson, GD. Potassium responses of various crops in East Africa. In: Proceedings of the $10^{\text {th }}$ Colloquium of the International Potash Potash Insititute, Abijan, Ivory Coast. International Potash Insititute, Abijan. Pp. 413-437; 1973. 
[59] Gourley, CJP. Potassium. In "Soil Analysis: An Interpretation Manual" (K. I. Peverill, L. A. Sparrow and D. J. Reuter, eds.). CSIRO Publishing, Melbourne; 1999.

[60] Schwartz, HF and Coralles, MA. Nutritional disorders in beans. In: Schwartz HF, Coralles MAP (Eds.) Bean production Problems in the tropics. Second edition. International Centre for Tropical Agriculture (CIAT), Cali. Pp. 75-604; 1989.

[61] Thomson, WW and Weier, TE. The fine structure of chloroplasts from mineral-deficient leaves of Phaseolus vulgaris. Amer J Bot. 49: 1047-1055; 1962.

[62] Marinos, NG. Studies on submicroscopic aspects of mineral deficiencies. II. Nitrogen, potassium, sulfur, phosphorus and magnesium deficiencies in the shoot apex of barley. Amer $\mathrm{J}$ Bot. 50: 998-1005; 1963.

[63] Evans, HJ and Sorger, GJ. Role of mineral elements with emphasis on the univalent cations. Annu Rev Plant Physiol. 17:47-76; 1966.

[64] Hall, JD, Barr R, Al-Abbas, AH, and Crane, FL. The ultra structure of chloroplasts in mineral deficient maize leaves. Plant Physiol. 50: 404-409; 1972.

[65] Marx, ES, Hart, J and Stevens, RG. Soil test interpretation guide. Oregon State University Extension Services. Oregon State University, Corvallis. 7pp; 1996.

[66] Cregan, DD, Hirth, JR, and Conyers, MK. Amelioration of soil acidity by liming and other amendments. In "Soil Acidity and Plant Growth" (A. D. Robson, Ed.), pp.205-264. Academic Press, Sydney;1989.

[67] McCray, JM and Sumner, ME. Assessing and modifying Ca and Al levels in acid subsoils. Adv Soil Sci. 14: 45-75; 1990.

[68] Cox, FR, Sullivan, GA, Martin, CK. Effect of calcium and irrigation treatments on peanut yield, grade and seed quality. Peanut Sci. 3:81-85; 1976.

[69] Hadidi, NA. The influence of macronutrient deficiency on plant growth and development, fruit yield, seed yield and quality of tomato (Lycopersicon esculentum Mill.) and cucumber (Cucumis sativus L.). Ph. D. Diss. (Diss. Abstr. AAT 8426398). The Ohio State University, Columbus; 1984.

[70] Frost, DJ, Kretchman, DW. Calcium deficiency reduces cucumber fruit and seed quality. J Am Soc Hort Sci. 114: 552$556 ; 1989$.

[71] Smiciklas, KD, Mullen, RE, Carlson, RE, Knapp, AD. Drought-induced stress effect on soybean seed calcium and quality. Crop Sci. 29: 1519-1523; 1989.

[72] Sanchez, PA, Logan TJ. Properties and management of soils in the tropics. John Wiley and Sons, New York. pp 618; 1992.
[73] Van Dijk, H. Colloid chemical properties of humic matter. In: McLaren AD, Skujins J (Eds.), Soil Biochemistry, Vol. 2. Marcel Dekker, New York, pp.16-35; 1971.

[74] Oades, JM, Gillman, GP, Uehara, G, Hue, NV, van Noordwijk, M, Robertson, GP, Wada, K. Interactions of soil organic matter and variable-charge clays. In: Coleman, DC, Oades, JM, Uehara, G (Eds), Dynamics of Soil Organic Matter in Tropical Ecosystems. University of Hawaii Press, Honolulu, HI, pp. 69-95; 1989.

[75] Lebron, I, Suarez, DL, Yoshida, T. Gypsum effect on the aggregate size and geometry of three sodic soils under reclamation. Soil Sci. Soc. Am. J. 66: 92-98; 2002.

[76] Aslam, M, Hukffker, RC, Rains, DW. Early effects of salinity on nitrate assimilation in barley seedlings. Plant Physiol. $76: 321-325 ; 1984$

[77] Seeman, JR, Sharkley, TD. Salinity and nitrogen effects on photosynthesis, ribulose-1, 5-bisphosphate carboxylase and metabolite pool sizes in Phaseolus vulgaris L. Plant Physiol. 82: $555-560 ; 1986$

[78] Tarczynski, MC, Jensen, RG and Bohnert, HJ. Stress protection of transgenic tobacco by production of the osmolyte mannitol. Sci. 259: 508-510; 1993.

[79] Munns, R. Physiological processes limiting plant growth in saline soils: some dogmas and hypotheses. Plant Cell Environ. 16: $15-24 ; 1993$.

[80] Noble, CL and Rogers, MJE. Response of temperate forage legumes to water logging and salinity. In: Pessarakli M (ed) handbook of Plant and crops stress. Marcel Dekker. Inc., New York, NY, pp.473-496; 1993.

[81] Gouia, H, Ghorbal MH, Touraine B. Effect of $\mathrm{NaCl}$ on flows of $\mathrm{N}$ and mineral ions and on $\mathrm{NO}_{3}{ }^{-}$reductase rate within whole plants of salt-sensitive bean and salt-tolerant cotton. Plant Phyisol. 105:1409-1418;1994.

[82] Murguia, JR, Belles, JM and Serrano, R. A salt-sensitive 3' (2'), 5'-bisphosphate nucleotidase involved in sulfate activation. Sci. 267: 232-234; 1995.

[83] Flowers, TJ. Salinisation and horticultural production. Sci Hort. 78: 1-4; 1999.

[84] Clark, GJ, Dodgshun, N, Sale, PWG, Tang, C. Changes in chemical and biological properties of sodic clay subsoil with addition of organic amendments. Soil Biol. Biochem. 39 (11): 2806-2817; 2007.

[85] Lombin, G and Fayemi, AA. Magnesium availability in soils from Western Nigeria. Soil Science. 122: 91-99; 1976. 